\title{
An early weather diary from Iberia (Lisbon, 1631-1632)
}

\section{Fernando Domínguez- \\ Castro, ${ }^{1,2}$ Ricardo \\ García-Herrera ${ }^{3,4}$ \\ and José $M$. Vaquero ${ }^{2}$}

${ }^{1}$ Facultad de Ingeniería Civil y Ambiental, Escuela Politécnica Nacional, Quito,

Ecuador

${ }^{2}$ Departamento de Física, Universidad de Extremadura, Mérida, Spain

${ }^{3}$ Departamento Física de la Tierra II, Universidad Complutense de Madrid, Spain

${ }^{4}$ GGEO, Instituto de Geociencias (UCM(ISC), Madrid, Spain

\section{Introduction}

Documentary sources are a useful tool to analyse climate in the pre-instrumental era, especially in places with a long writing tradition (see Jones et al. (2009) and Brázdil et al. (2005; 2010) for review articles). They include a wide typology, from any piece of paper to paintings or markers. These sources provide a great range of information, including direct evidence (descriptions of weather or extreme events) and climate proxies (dates of crop collections, blooming, rogation ceremonies, icebreaking etc). Among them, weather diaries provide first-hand information in a sequential and mostly continuous way, with precise dating reaching, sometimes, subdaily resolution. Their time coverage ranges from months (e.g. Carlo de Zinzendorf weather diary at Trieste, from June 1776 to June 1777; see Pagnini, 1978) to almost a lifetime (e.g. Haller Wolfagang diary from Zurich, from 1545 to 1576; see Flohn, 1949). Sometimes longer weather diaries can be found when they are supported by an institution and compiled by many authors, such as the Premonstratensian Abbey diary at Hradisko that covers the period 1693-1783 (Brázdil et al., 2008). However, in this case the climate perception can vary depending on the author and this can lead to homogeneity problems.

Many weather diaries have been found and studied in Italy (Raicich, 2008), central Europe (Pfister et al., 1999), Czech Republic
2008), Slovakia (Brázdil and Kiss, 2001) and Japan (Maejima, 1966; Takehiko, 1993). Logbooks are a specific type of weather diary and they provide information about climate in the world oceans (see Wheeler and García-Herrera (2008) for a review).

In Iberia documentary sources have allowed retrieving information on extreme events as early as the eighth century (Domínguez-Castro et al., 2014b). Most of the documentary evidence comes from administrative (civil or ecclesiastic) institutions. Due to the Iberian climate and agriculture, most of the records are associated with precipitation. Thus, series of rogation ceremonies from 1500 have been compiled for different locations (Barriendos, 1997; Vicente Serrano et al., 2007), allowing the study of the changing pattern of droughts (Domínguez-Castro et al., 2010; 2012). Floods have also been studied extensively in most of the Spanish basins (see Barriendos and Rodrigo, 2006). However, weather diaries are very scarce, with serial descriptions of weather mostly attached to the early meteorological measurements (Domínguez-Castro et al., 2013; 2014a). Here we study the weather dairy compiled by Antonio de Nájera in Lisbon (Figure 1) from 1631 to 1632, almost a century earlier than the first instrumental observations, which were performed in Lisbon in

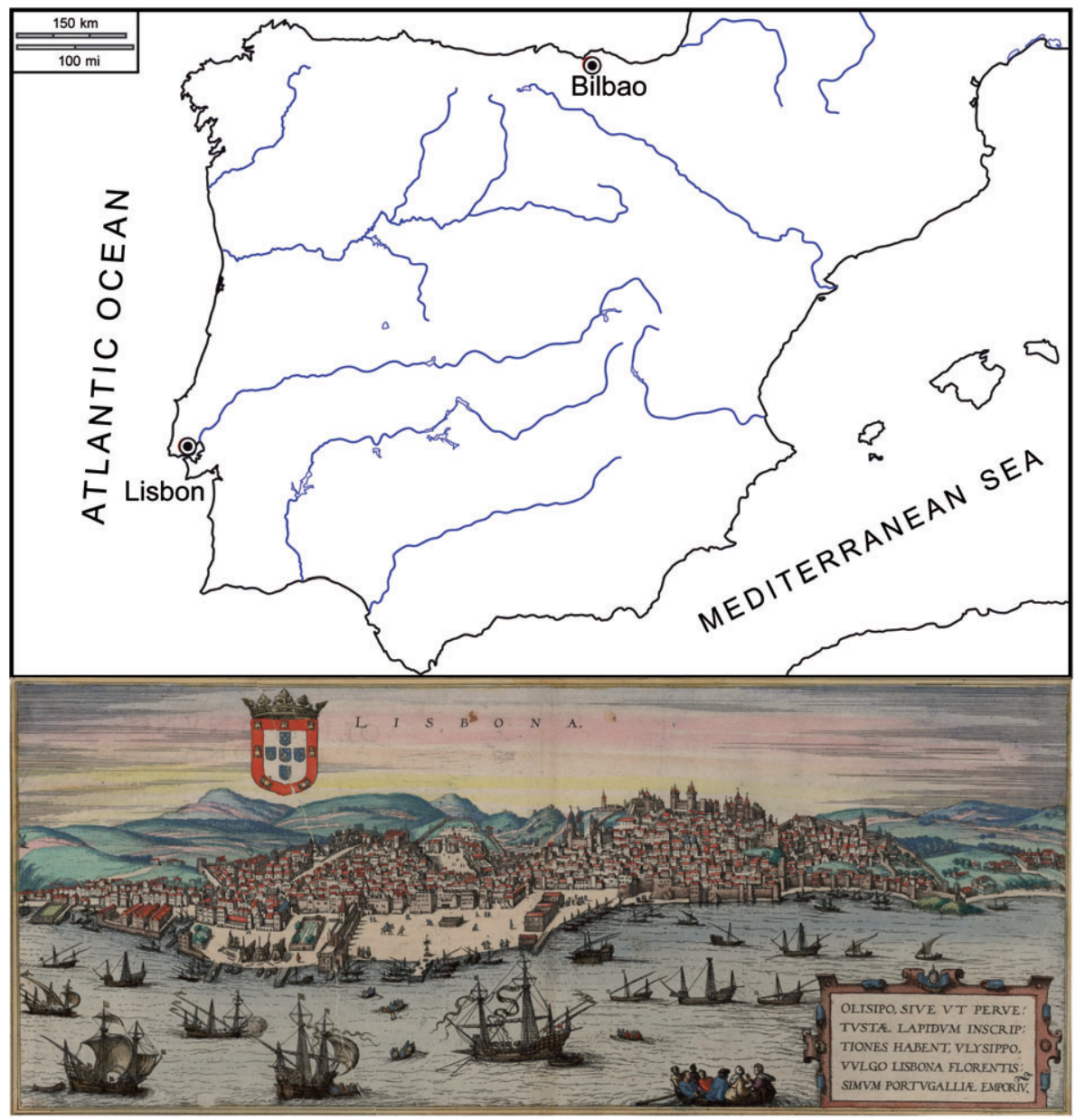

Figure 1. Map of the lberian peninsula with location of cities cited in the text and major drainage basins, together with a panoramic view of Lisbon from the Civitates Orbis Terrarum of Georg Braun and Franz Hogenberg published between 1575 and 1618. 
1724 (Domínguez-Castro et al., 2013). This is a period with few high-resolution climatic reconstructions in Iberia: a summer temperature reconstruction based in tree-rings from the Pyrenees (Dorado Liñan et al., 2012), a seasonal reconstruction of rainfall based in documentary extreme events from Andalusia (Rodrigo et al., 1999) and a winter rainfall reconstruction based in calcite lamination in Lake La Cruz (Cuenca) (Romero-Viana et al., 2011). All of them have lower resolution than the daily/subdaily record provided by de Nájera's diary.

\section{The author}

Few details are known about the life of Antonio de Nájera. His family came from Spain but he was born in Lisbon in the late sixteenth or early seventeenth century, a period when Spain and Portugal were united under Philip IV. During his early youth, he showed interest in mathematics and went to Spain to study (FernándezNavarrate, 1846). He was a mathematician with great interest on cosmography, navigation and astronomy. He became Prime cosmographer of the King in the three regions of the Cantabric coast.

A brief summary of his publications can help in understanding his interests and expertise. In 1619, he published a short text about the 1618 comet (de Nájera, 1619) where he provides a general description of comets, cites their effects, such as winds, epidemics, earthquakes, wars, and also writes about natural astrology explaining the effects of the comets on agriculture, navigation and meteorology.

In 1628 he published, in Lisbon (de Nájera, 1628), an important manual of navigation that was used extensively during the seventeenth and eighteenth centuries. In this work he corrected the tables of the Sun and stars with the observations of Tycho-Brahe. This book was divided in three parts corresponding with the three principal instruments in navigation: astrolabe, ship's compass and nautical chart. Especially appreciated were the observations and instructions to navigate from the Cape of Good Hope to the East Indies.

Summa astrologica (de Nájera, 1632) focuses on the astrological prediction of weather. To the best of our knowledge, the first written references related to astrometeorology were by the Babylonians around the seventh century $B C$, written in cuneiform script and preserved in the Library of Ashurbanipal, for example When it thunders in the day of the moon's disappearance, the crops will prosper and the market will be steady (Shaw and Austin, 1932). The first weather diary with a clear astro-meteorological objective that has been preserved, however, is William Merle's diary recorded from 1337 to 1344 in Oxford and Lincolnshire (Geneva, 1995).
Astro-meteorology was popular in Europe during the sixteenth and seventeenth centuries. At that time, many almanacs or ephemerids with astronomical and meteorological observations were published. Planetary astronomy was the main tool used to explain and predict the weather at that time. This approach was continued into the eighteenth century by people such as Joseph Toaldo, who made meteorological observations from 1766 to 1797 in Padova, looking for their relation with phases of the moon (Camuffo, 2002). De Nájera is part of this tradition and compiled information from Greek (Ptolemy) and Arabian (Abu Massar and Al Kindi) astrologers. The book contains a great number of aphorisms on constellations that affect the weather. In fact, he wrote his diary to validate the aphorisms compiled in this text. It is important to note that the separation process between astronomy and astrology occurred just at this time (Vernet, 2000). Carolino (2003) offers more information on the role of astrology in the science and society of Lisbon in the seventeenth century.

\section{The diary}

The unpublished manuscript is preserved in the Spanish National Library; it has 359 pages and its precise date of writing is unknown. The diary is a collection
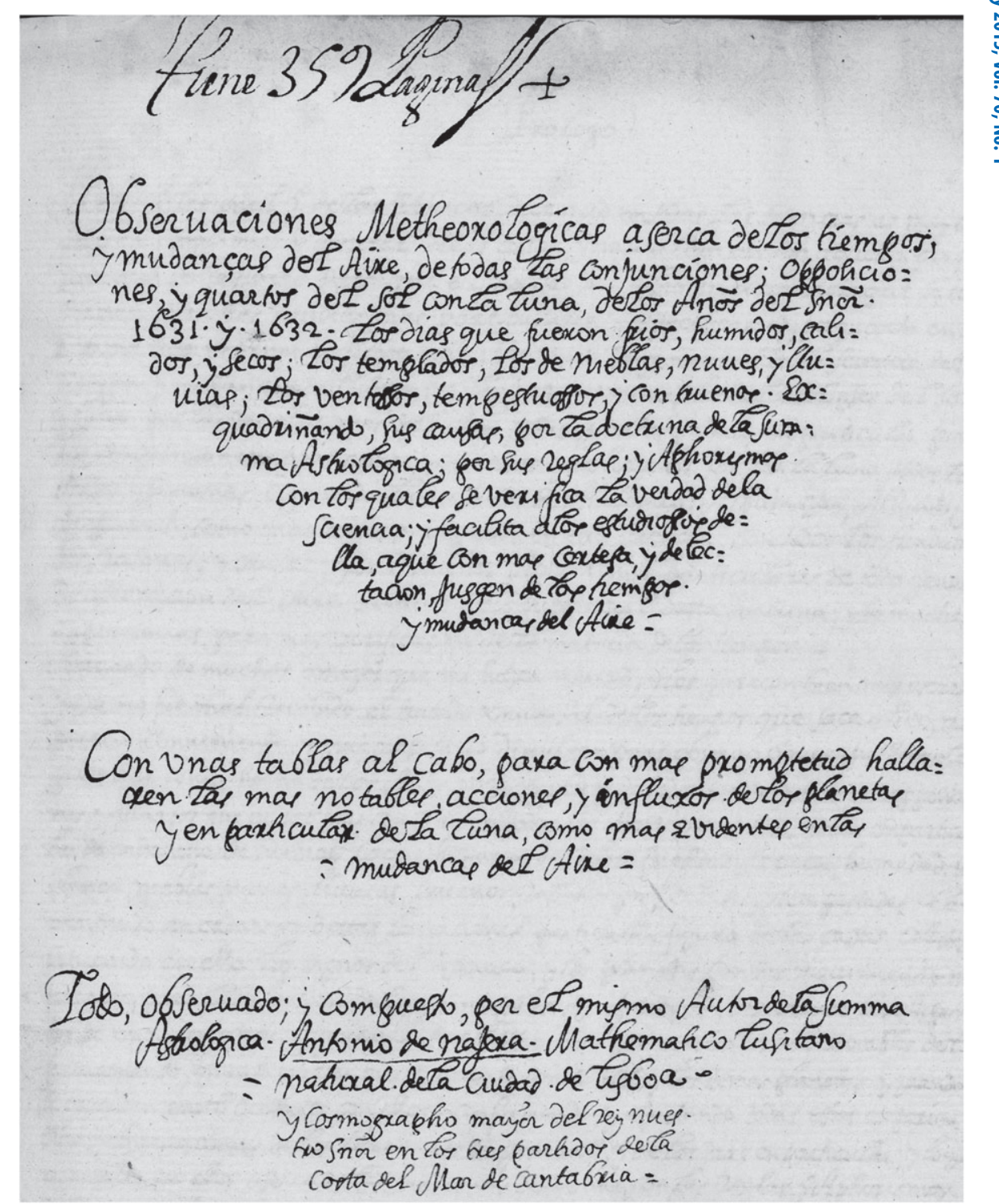

Figure 2. Title page of de Nájera's manuscript. (Courtesy of Spanish National Library.) Meteorological observations about the weather and changes of the air, of all the conjunctions; oppositions and quarters of the sun and moon, from the years of Our Lord 1631 and 1632. The days that were cold, wet, hot, and dry; the mild, with fog, clouds and rain; the windy; stormy, and with thunder. Scrutinising, its causes by the Summa Asthologica; its rules; and aphorism with which to verify the truth of the science; and make easier for the scholar, although with more certainty, and delectation urge of the weather and changes of the air. With tables at the ending, for easily finding the most prominent actions and influx of the planets and in particular of the moon, as more evident in the changes of the air. 
of daily meteorological and astronomical observations from 19 December 1630 to 2 January 1633, including discussions on their possible relationship. The manuscript has a long and descriptive title, see caption in Figure 2, and is written in Spanish.

De Nájera provides daily descriptions of the weather and movements of the stars, trying to explain the weather variations by the position of the celestial bodies. At the end of every lunar month, he summarises both weather and astronomy.

Only 17 days (2\%) have no meteorological information during the studied period. The weather descriptions make reference to cloudiness, rainfall, temperature, wind and other features such as fog, lightning, thunder or hail in a homogeneous style. The descriptions are usually short and concise, such as clear, hot and dry (29 July 1631), but they can be longer, depending on the changes of the atmosphere through the day all the previous night rain, winds with hail, thunderstorms and lightnings until the early morning, during the morning wet clouds with some little rain, during the afternoon better day and during the night more rain (19 November 1632).

All the weather descriptions have been transcribed and will be available on the website of the KLIMHIST project (http:// clima.ul.pt/klimhist).

\section{Indexation}

We have applied content analysis (Baron, 1982) to index the different climate variables depending on the frequency of the variable in the reports, the extent of the description and the intensity of the phenomenon.

\begin{tabular}{|ll|}
\hline Table 1 \\
\hline Value index for the adjectives used by de Nájera describing temperature. \\
\hline Temperature index & Adjectives used by de Nájera \\
\hline+2 Very hot & Mucho calor, muy caluroso, muy cálido, grandes calores \\
+1 Hot & Cálido, Caluroso, calor, calores, algún calor, cálidos \\
0 Normal & Templado, buen día \\
-1 Cold & Frío, frías, algo frio, frescos \\
-2 Very cold & Muy frío, aire de nieve, grande frío \\
\hline
\end{tabular}

\section{Table 2}

As Table 1 but for precipitation.

Raifall index Adjectives used by de Nájera

+3 Heavy rainy Diluvios de aguas, muchísima lluvia, muy grande tempestad de lluvia gruesa, mucha lluvia con tempestades, grandes tempestades de agua

+2 Moderate rain Mucha lluvia, Muy lluvioso, llovió muy bien, llovía bastante, lluvia gruesa, lluvias continuas, con mucha agua, exceso de lluvias, grandes lluvias

+1 Light rain Lluvia menuda, un poco de lluvia, lluvia blanda, algunas lluvias, pocas lluvias, lluvioso con blandura, lluvias finas, lluvia, lluvioso

\section{Wind}

Information about the wind is scarce. Only 115 days show information about the wind direction and 99 days about wind force. We have categorised the wind force in two classes: weak (vientos, algun viento, ventoso) and strong (vientos fuertes, grandes vientos, vientos recios, vientos fieros, vientos ofuscados, tempestad de viento, vientos avendavales). This variable cannot be considered as continuous, such that we consider no data when de Nájera does not make reference to the wind.

\section{Other weather events}

We have compiled the presence of other weather events as fog, hail, thunder and lightning.

\section{Results and discussion}

Figure 3 shows the temperature and precipitation indices and the cloudiness and fog frequencies. We can see clearly the annual cycle with hot, dry and clear summers and cold, rainy and overcast days during the winter. The summer of 1631 was hotter than the summer of 1632 , with July of 1631 being the hottest month. The coldest month was February 1632. The spring of 1632 was the wettest period, with 57 rainy days. A high concentration of fog occurred from 12 January to 3 February 1632, when almost all the days (14) record references to fog. This episode could be related to the most violent and destructive eruption of the Vesuvius volcano (Naples, Italy) in recent history. This eruption started at 7 a.m. local time on 16 December and was a Plinian eruption with an estimated tephra volume $0.07 \mathrm{~km}^{3}$ and peak mass flux erupted in the range $3-6 \times 10^{7} \mathrm{kgs}^{-1}$, corresponding to a column height of $17-21 \mathrm{~km}$ (Rosi et al., 1993).

\section{Comparison with Lisbon current climate}

\section{Cloudiness}

We have used the cloudiness data of Lisbon published in the Annals of the Infante D. Luiz Geophysical Observatory. These data have monthly resolution and cover the period 1855-1940 with a scale from 0 (completely clear) to 10 (completely covered). In order to compare with de Nájera's observations, we have transformed our three categories (clear, cloudy and covered) into numeric values. Taking into account that de Nájera did not observe continuously and only annotated the more relevant changes, we have assigned a value of 8 for covered, 5 for cloudy and 2 for clear. Next we have computed the monthly averages and compared them with the corresponding Geophysical Observatory 


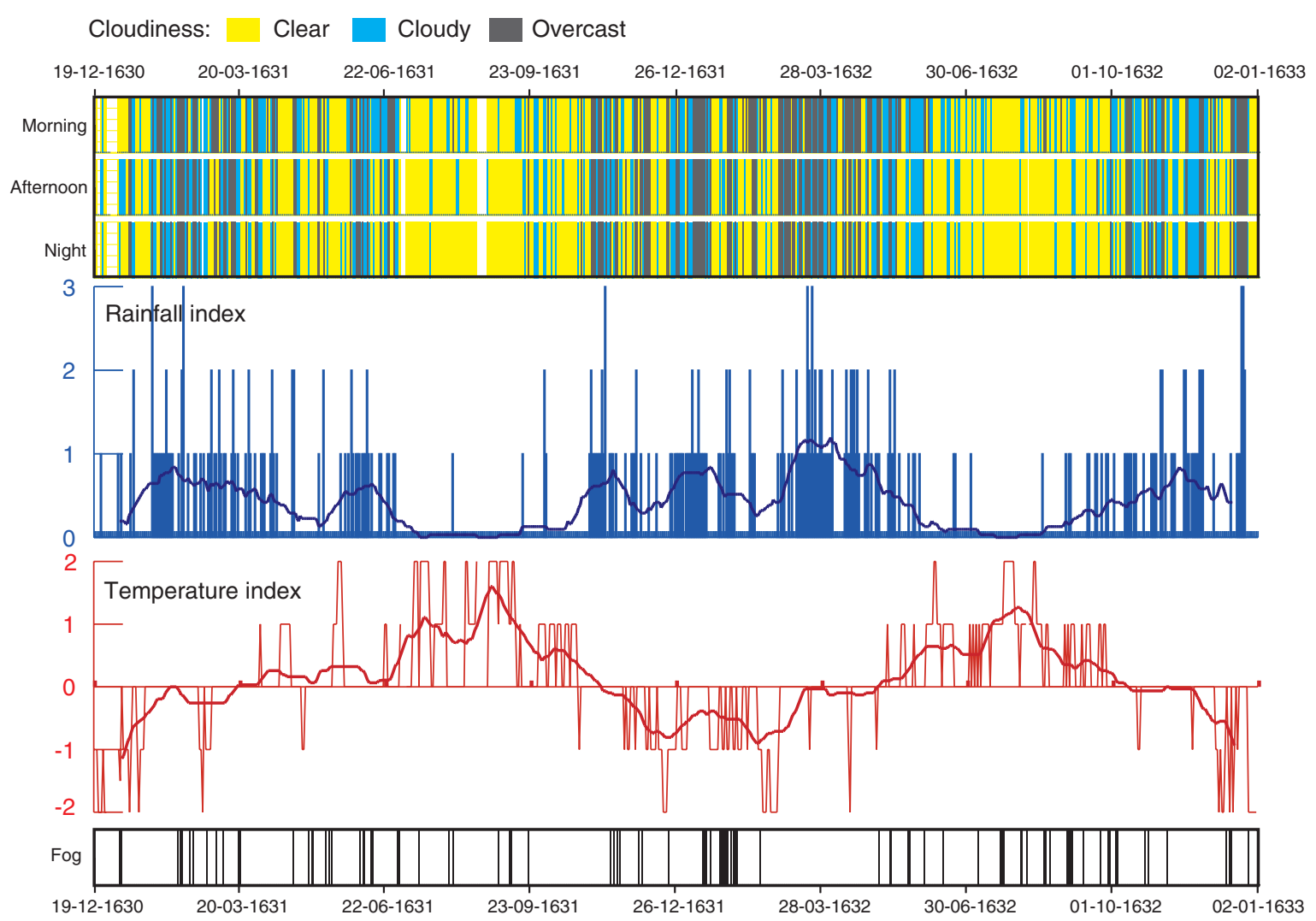

Figure 3. Meteorological information extracted from de Nájera's weather diary, from top to bottom, cloudiness, temperature index (solid line: 31-day moving average), rainfall index (solid line: 31-day moving average) and fog.
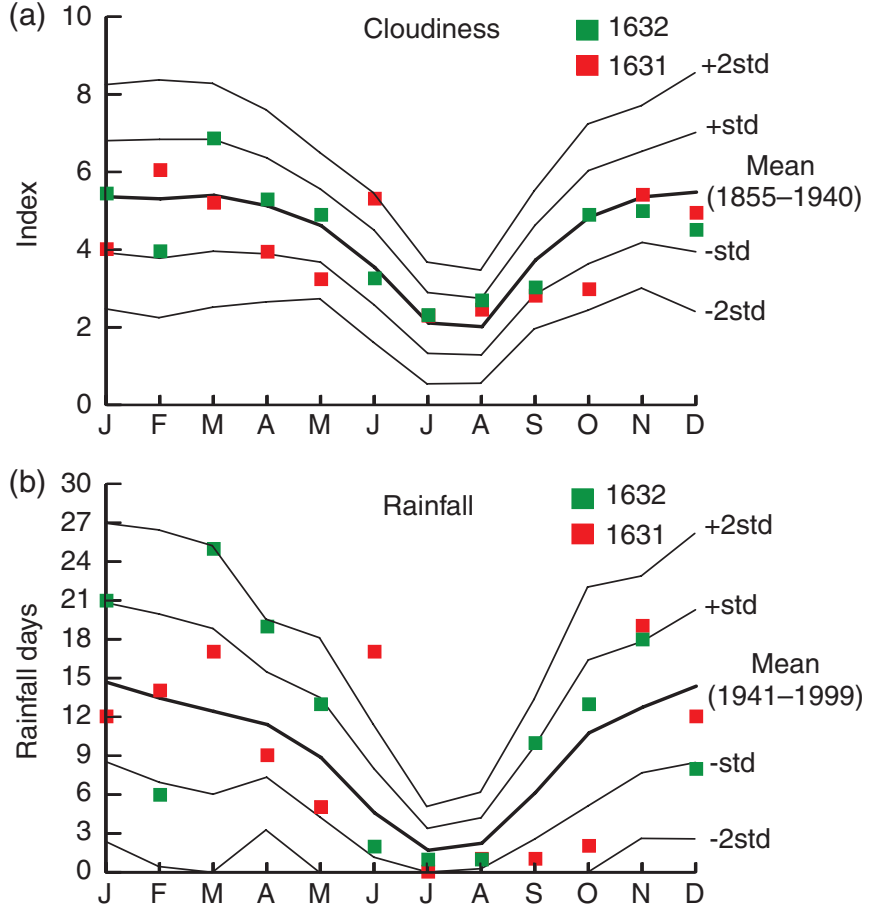

Figure 4. (a) Monthly values of cloudiness for 1631 (red squares) and 1632 (green squares) in comparison with the long term averages 1855-1940 (bold solid line, mean; thin solid line, one and two standard deviations). (b) Monthly frequency of days with precipitation in 1631 (red squares) and 1632 (green squares) in comparison with the long term 1941-1999 (bold solid line, mean; thin solid line, one and two standard deviations).

values. The results are shown in Figure 4(a). In general, the 1632 and 1631 observations follow the 1855-1940 pattern, with clear summers and cloudy winters. July 1631 seems to have been the month with the highest anomaly, while May and October were clearer than usual. In general, the 1632 values are closer to the 1855-1940 averages (all the data within one standard deviation) than those from 1631.

\section{Rainfall}

We have used as reference the rainfall data of the Lisbon Geophysical station from 1941 to 1999 (Klein Tank et al., 2002; downloaded from http://www.ecad.eu). To reduce the uncertainties we have compared only the monthly frequency of rainy days. It can be seen (Figure 4(b)) that many months are above the long-term average. This is an unexpected result, because weather diaries tend to underestimate precipitation frequency because observations are not continuous through the day, and rain is scarcely recorded when it is light or occurs at night. With this is mind, the spring of 1632, with 57 rainy days, was very wet, as compared with a maximum of 51 days during the rainiest spring of the reference period (1946). Rain was continuous during the period from 13 March to 5 April of 1632. June 1631 was also very rainy (17 days) when compared with the reference period, which showed a maximum frequency of 15 days (1988). The wet character of June 1631 seems to have affected other regions in Iberia, thus, in the Chapter Proceedings of the Cathedral of Bilbao (Figure 1), a collectio pro serenitate is recorded on 12 June 1631 (Barriendos, 1997).

In contrast, October 1631 seems to have been particularly dry. September 1631 could also have been a dry month, because it contains only one rainy day, however, data for this month are not representative because it has seven missing days. Anyway the dry nature of the 1631 autumn was not exclu- 
sive to Lisbon. Again in Bilbao a collectio pro pluvia was held on 10 October (Barriendos, 1997), which suggests that the drought also affected northern Iberia.

As we explained in the introduction, comparison with other Iberian proxies is difficult. Only Rodrigo et al. (1999) shows seasonal precipitation information for this period, but unfortunately the index value for summer and autumn of 1631 and spring of 1632 is 0 , which means that climate was normal in Andalusia or the reconstruction has a lack of information for these years.

\section{Concluding remarks}

De Nájera's diary is the earliest weather diary found and studied in the Iberian territories until now. The information obtained from this diary has higher time resolution (daily and, even, subdaily) and provides more details than any other contemporary source.

Our results show that de Nájera's dairy describes accurately the weather of Lisbon, with a good reproduction of the annual cycle. We can highlight the concentration of rainy days during June 1631 and the spring of 1632. Unfortunately, there are no highresolution precipitation proxies in Iberia to compare with de Nájera's observations. This restricts the evaluation of de Nájera's record in terms of the Iberian climate. The compilation of new proxies or observational data should allow us to assess the spatial extent of the detected anomalies and the possible effects of the Vesuvius eruption of 1631 in Iberia.

\section{Acknowledgements}

This research was supported by the Fundacão para a Ciência e a Tecnologia (project KlimHist PTDC/AAC-CLI/119078/2010) and the Spanish Ministry of Science and Innovation (project AYA2008-04864/AYA). Fernando Domínguez-Castro was supported by the Ecuadorian Government (Secretaría de Educación Superior, Ciencia, Tecnologia e Innovación) through a PROMETEO project.

\section{References}

Baron WR. 1982. The reconstruction of eighteenth century temperature records through the use of content analysis. Clim. Change 4: 385-398.

Barriendos M. 1997. Climatic variations in the Iberian peninsula during the late Maunder minimum (AD 1675-1715): an analysis of data from rogation ceremonies. Holocene 7: 105-111.

Barriendos M, Rodrigo FS. 2006. Study of historical flood events on Spanish rivers using documentary data. Hydrol. Sci. J. 55(5): 765-783.

Brázdil R, Kiss A. 2001. Daily Weather Observations at Košice, Slovakia in the
Period 1677-1681, Meteorologický časopis. Slovenský Hydrometeorologický Ústav: Bratislava.

Brázdil R, Kotyza O. 1996. The earliest daily weather records in the Czech Lands and their utilisation for the reconstruction of climate. Weather 51: 341-349.

Brázdil R, Pfister C, Wanner H et al. 2005. Historical climatology in Europe - the state of the art. Clim. Change 70: 363-430. Brázdil R, Černušák T, Řezníčková L. 2008. Weather information in the diaries of the Premonstratensian Abbey at Hradisko, in the Czech Republic, 1693-1783. Weather 63: 201-207.

Brázdil R, Dobrovolný P, Luterbacher J et al. 2010. European climate of the past 500 years: new challenges for historical climatology. Clim. Change 101(1-2): 7-40.

Camuffo D. 2002. History of the long series of daily air temperature in Padova (1725-1998). Clim. Change 53: 7-75.

Carolino LM. 2003. Ciência, Astrologia e Sociedade: A Teoria da Influência Celeste em Portugal (1593-1755). Fundação Calouste Gulbenkian: Lisbon.

de Nájera A. 1619. Discursos Astrologicos Sobre o Cometa que Apareceo em 25 de Novembro de 618. Pedro Craesbeeck: Lisbon.

de Nájera A. 1628. Navegacion Especulativa y Practica, Reformadas sus Reglas y Tablas por las Observaciones de Ticho Brahe, con Emienda de Algunos Yerros Essenciales, todo Provado con Nuevas Supposiciones Mathematicas y Demosntraciones Geometricas... Pedro Craesbeeck: Lisbon.

de Nájera A. 1632. Summa Astrologica y Arte Para Hazer Pronósticos de los Tiempos.... Antonio Alvarez: Lisbon.

Domínguez-Castro F, García-Herrera R, Ribera $P$ et al. 2010. A shift in the spatial pattern of Iberian droughts during the 17th century. Clim. Past 6: 1111-1137.

Domínguez-Castro F, Ribera P, GarcíaHerrera R et al. 2012. Assessing extreme droughts in the Iberian Peninsula during 1750-1850 from rogation ceremonies. Clim. Past 8: 705-722.

Domínguez-Castro F, Trigo RM, Vaquero JM. 2013. The first meteorological measurements in the Iberian Peninsula. Clim. Change 118(2): 443-455.

Domínguez-Castro F, Vaquero JM, Rodrigo FS et al. 2014a. Early Spanish meteorological records (1780-1850). Int. J. Climatol. 34(3): 593-603, doi: 10.1002/ joc.3709.

Domínguez-Castro F, de Miguel JC, Vaquero JM et al. 2014b. Climatic potential of Islamic chronicles in Iberia: extreme droughts (AD 7111010). The Holocene 24(3): 370-374, doi:10.1177/0959683613518591.

Dorado Liñan I, Büntgen U, González-Rouco F et al. 2012. Estimating 750 years of temperature variations and uncertainties in the Pyrenees by tree-ring reconstructions and climate simulations. Clim. Past 8: 933.

Fernández-Navarrate M. 1846.

Disertación Sobre la Historia de la Náutica y de las Ciencias Matemátcas que han Contribuido a sus Progresos Entre los Españoles. Madrid: Imprenta de la Viuda de Calero.: Madrid
Flohn H. 1949. Klima und witterungsablauf in Zürich im 16 jahrhundert. Vierteljahrsschr. Naturforsch. Ges. Zürich 94: 28-41.

Geneva A. 1995. Astrology and the Seventeenth Century Mind: William Lilly and the Language of the Stars. Manchester: Manchester University Press: Manchester, UK.

\section{Jones PD, Briffa KR, Osborn TJ et al.}

2009. High-resolution palaeoclimatology of the last millennium: a review of current status and future prospects. The Holocene 19: 3-49.

Klein Tank AMG, Wijngaard JB, Können GP et al. 2002. Daily dataset of 20th-century surface air temperature and precipitation series for the European Climate Assessment. Int. J. Climatol. 22: 1441-1453.

Maejima I. 1966. Some remarks on the climatic conditions of Kyoto during the period from 1474 to 1533 A.D. Geogr. Rep. Tokyo Metrop. Univ. 1: 103-111.

Pagnini C. 1978. II Periodo triestino del diario linedito del conte Carlo de Zinzendorf primo governatore di Trieste (1776-1777). Archeogr. Triest. 38: 3-247.

Pfister C, Brázdil R, Glaser R et al. 1999. Daily weather observations in sixteenth century Europe. Clim. Change 43: 111-150.

Raicich F. 2008. Some features of Trieste climate from an eighteenth century diary (1732-1749). Clim. Change 86: 211-226.

Rodrigo FS, Esteban-Parra MJ, PozoVázquez D et al. 1999. A 500-year precipitation record in southern Spain. Int. J. Climatol. 19: 1233-1253.

Romero-Viana L, Julià R, Schimmel M et al. 2011. Reconstruction of annual winter rainfall since A.D. 1579 in centraleastern Spain based on calcite laminated sediments from Lake La Cruz. Clim. Change 107(2-3): 343-361.

Rosi M, Principe C, Vecci R. 1993. The 1631 Vesuvius eruption. A reconstruction based on historical and stratigraphical data. J. Volcanol. Geotherm. Res. 58(1-4): 151-182.

Shaw N, Austin E. 1932. Manual of Meteorology: Meteorology in History. Cambridge University Press: Cambridge, UK

Takehiko M. 1993. Summer temperature variabilities in Japan reconstructed from diary weather records during the little ice age. J. Geogr. 102: 144-151.

Vernet J. 2000. Astrología y Astronomía en el Renacimiento: la Revolución Copernicana. El Acantilado: Barcelona, Spain.

Vicente Serrano SM, Cuadrat JM. 2007.

North Atlantic oscillation control of drought in north-east Spain: evaluation since 1600 A.D. Clim. Change 85: 357-379.

Wheeler D, García-Herrera R. 2008. Ships' logbooks in climatological research. Ann. N.Y. Acad. Sci. 1146: 1-15.

Correspondence to: Fernando Domínguez-Castro

f.dominguez.castro@gmail.com

(c) 2015 Royal Meteorological Society

doi:10.1002/wea.2319 